\title{
KEANEKARAGAMAN TUMBUHAN SUKU PIPERACEAE DI KAWASAN AIR TERJUN LOMBONGO PROVINSI GORONTALO
}

\section{THE PLANTS DIVERSITY OF PIPERACEAE TRIBE IN LOMBONGO WATERFALL AREA GORONTALO}

\author{
Muhammad Abdul Afif Mokodompit, Dewi Wahyuni K. Baderan, Syam S. Kumaji \\ Departemen Biologi, Fakultas Matematika dan Ilmu Pengetahuan Alam, Universitas \\ Negeri Gorontalo \\ Jl. Prof. B.J. Habibie, Tilongkabila, Bone Bolango 96583, Provinsi Gorontalo \\ Corresponding author : dewi.baderan@ung.ac.id
}

\begin{abstract}
Abstrak
Tumbuhan suku Piperaceae merupakan kelompok tumbuhan berbunga yang mempunyai ciri khas aromatik dan hidup di daerah hutan hujan tropika. Berdasarkan survei awal di kawasan air terjun Lombongo Provinsi Gorontalo, wilayah Taman Nasional Bogani Nani Wartabone, didapati berbagai spesies dari suku Piperaceae. Namun belum teridentifikasi jenis Piper apa saja serta bagaimana nilai indeks keanekaragaman di kawasan air terjun tersebut. Tujuan penelitian ini adalah untuk mengetahui bagaimana keanekaragaman jenis tumbuhan suku Piperaceae yang ada di kawasan air terjun Lombongo Provinsi Gorontalo. Teknik pengumpulan data menggunakan metode eksploratif atau jelajah dengan menggunakan teknik sampling Probability Sample. Hasil penelitian menemukan 9 jenis tumbuhan suku Piperaceae dengan dua cara hidup yang berbeda yakni, terstrial dan epifit. Nilai indeks keanekaragaman tumbuhan suku Piperaceae yang terdapat di kawasan air terjun Lombongo adalah 2.17 dengan kriteria sedang yang menunjukan keadaan ekosistem yang cukup stabil.
\end{abstract}

Kata kunci : Keanekaragaman, Piperaceae, Air Terjun , Lombongo

\begin{abstract}
Piperaceae is a group of flowering plants that have aromatic characteristics and live-in tropical rain forest areas. Based on the initial survey, various species of Piperacaea is found in the Lombongo waterfall, Gorontalo Province,Bogani Nani Wartabone National Park. However, all of them are not well-identified looking from its diversity index. This study seeks to examine the diversity of Piperaceae species in the Lombongo waterfall, Gorontalo. It uses the exploratory method for the data collections and will be produced through sample probability. The result shows that there are nine species of Piperaceae tribes with two different classifications, namely terrestial and epiphytic. The index value shows that the Piperacaeae that lives in Lombongo waterfall has 2.17 in a number which is moderate and indicates a fairly stable ecosystem condition.
\end{abstract}

Kata kunci : Diversity, Piperaceae, Waterfall, Lombongo 


\section{Pendahuluan}

Keanekaragaman (diversity) merupakan variasi dan juga variabilitas kehidupan di bumi. Menurut Baderan (2016) keanekaragaman merupakan perbedaan karakteristik antar komunitas. Keanekaragaman pada makhluk hidup dapat terjadi karena adanya perbedaan tekstur, warna, ukuran, jumlah, serta bentuk, yang merupakan karakteristik biologis untuk menyatakan struktur komunitasnya (Kristanto dkk, 2008). Keanekaragaman hayati (biodiversity) adalah keanekaragaman makhluk hidup yang meliputi keseluruhan atau totalitas variasi genetik, spesies, dan ekosistem pada suatu wilayah. Keanekaragaman mencakup makhluk hidup secara keseluruhan, di antaranya segala jenis flora atau dunia tumbuh-tumbuhan, termasuk tumbuhan dari suku Piperaceae.

Suku Piperaceae atau yang dikenal dengan nama lokal sirih, terdiri dari 13 marga dan perkiraan 7.123 nama spesies dari berbagai jenis dengan 2.658 nama spesies yang valid (The Plant List, 2021). Tumbuhan suku Piperaceae mempunyai peran penting bagi kehidupan masyarakat baik untuk kepentingan sosial, budaya, ekonomi dan juga pendidikan.

Tumbuhan Piperaceae tumbuh dan tersebar di daerah hutan hujan tropika, salah satunya di kawasan air terjun Lombongo, Kabupaten Bone Bolango, Provinsi Gorontalo. Berdasarkan PERDA Kabupaten Bone Bolango, Nomor 4 Tahun 2007 Lombongo merupakan kawasan wisata yang terletak di wilayah Taman Nasional Bogani Nani Wartabone (TNBNW) dengan berbagai objek wisata, salah satunya yaitu air terjun. Air terjun merupakan ruang terbuka yang berada di hutan, serta wahana alami yang berpotensi memiliki keanekaragaman jenis flora utamanya tumbuhan suku Piperaceae. Secara adminstratif, kawasan air terjun lombongo terletak di Desa Lombongo, Kecamatan Suwawa, Kabupaten Bone Bolango, Provinsi Gorontalo, yang merupakan bagian dari sungai Boliohuto. Jarak Lombongo dari arah timur Kota Gorontalo sekitar $19 \mathrm{~km}^{2}$, dengan waktu tempuh menggunakan kendaraan sekitar 30 menit sampai pada pintu masuk objek wisata Lombongo. Kawasan air terjun Lombongo merupakan salah satu habitat alami bagi tumbuh-tumbuhan yang hidup dengan baik di sekitarnya. Air terjun lombongo berjarak sekitar $4 \mathrm{~km}^{2}$ dari pintu masuk obyek pemandian air panas lombongo dengan jarak tempuh sekitar 1-2 jam perjalanan. Adapun jalur yang ditempuh yakni melalui Daerah Aliran Sungai (DAS), melewati jembatan gantung, hingga setapak menanjak dengan ragam bebatuan.

\section{Metode Penelitian}

\section{Tempat dan Waktu Penelitian}

Penelitian ini dilaksanakan mulai bulan Desember 2020 sampai Februari 2021 di wilayah Rintisan Geopark, Kawasan Air Terjun Lombongo, Kabupaten Bone Bolango, Provinsi Gorontalo. 


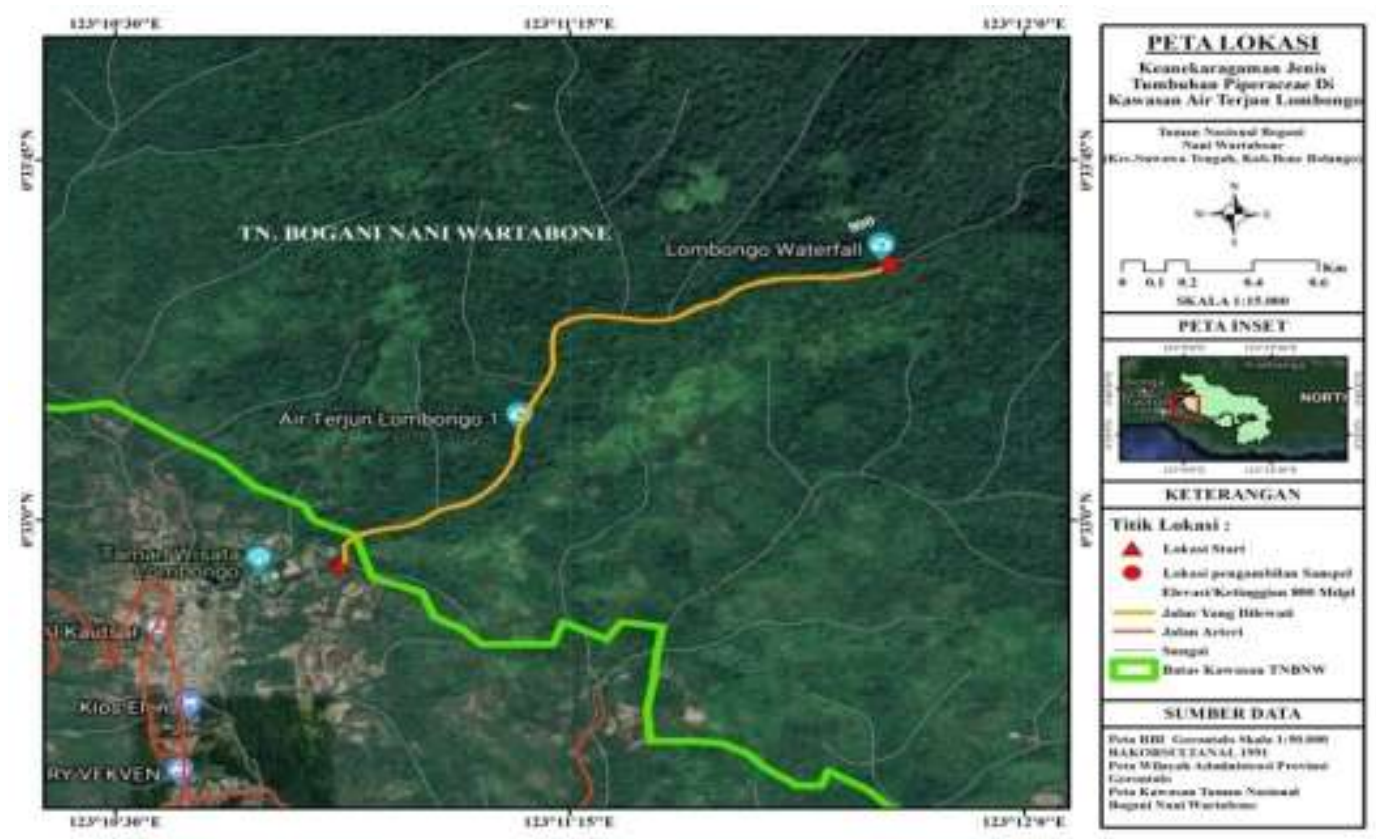

Gambar 1. Peta Lokasi Penelitian

\section{Obyek dan Metode Penelitian}

Obyek pada penelitian ini adalah semua jenis tumbuhan dari suku Piperaceae yang ada di wilayah Rintisan Geopark, Kawasan Air Terjun Lombongo, Kabupaten Bone Bolango, Provinsi Gorontalo dan penelitian ini dilakukan dengan menggunakan metode jelajah secara eksploratif atau acak terwakili dengan menggunakan teknik sampling Probability Sample (Sugiyono, 2018) pada lokasi penelitian di wilayah Rintisan Geopark, Kawasan Air Terjun Lombongo, Provinsi Gorontalo.

\section{Alat dan Bahan Penelitian}

Alat-alat pada penelitian ini yaitu GPS (Global Position System), Hygrometer untuk mengukur kelembaban udara, Thermometer untuk mengukur suhu udara, Soil Tester untuk mengukur $\mathrm{pH}$ dan suhu tanah, kamera digital digunakan untuk keperluan dokumentasi gambar tumbuhan sebagai bukti fisik penelitian, kunci determinasi, serta alat Tulis menulis, mistar, etiket gantu, kain hitam dan peta. Adapun bahan pada penelitian ini ialah semua jenis tumbuhan dari suku Piperaceae.

\section{Prosedur Penelitian}

Tindakan pertama yang dilakukan ialah pengamatan awal atau observasi, bertujuan untuk mengamati langsung kondisi lokasi yang akan dijadikan tempat penelitian dari obyek yang akan diteliti guna mendapaktan informasi-informasi yang dibutuhkan untuk melanjutkan penelitian.

Teknik pengambilan data dilakukan dengan menggunakan metode jelajah atau eksplorasi, yaitu dengan berjalan menyelusuri setiap sudut lokasi yang telah ditetapkan dalam hal ini kawasan air terjun Lombongo, serta menghitung jumlah sampel tumbuhan Piperaceaeyang dijumpai selama perjalanan dalam lokasi penelitian. Sampel kemudian diidentifikasi dan didokumentasikan sebagai bukti fisik. Metode ini digunakan karena melihat lokasi penelitian memiliki geografis yang terjal serta terdapat tebing yang cukup tinggi sebagai aliran dari air terjun yang terdapat di lokasi penelitian. Selain itu dilakukan pengukuran faktor lingkungan meliputi suhu udara, kelembaban udara, $\mathrm{pH}$ dan suhu tanah serta ketinggian lokasi pada lokasi penelitian. 
Identifikasi dilakukan dengan memperhatikan karakteristik morfologi. Cara mengidentifikasi yaitu dimulai dengan mengamati sampel yang masih berada pada substrat alami, kemudian diamati ciri-ciri morfologinya secara makroskopik meliputi akar, batang, daun, bunga dan buah, kemudian disesuaikan dengan kunci determinasi berdasarkan urutan taksonominya. Selanjutnya, sampel didokumentasikan.

\section{Analisis Statistik}

Analisis data yang diperoleh dari lokasi penelitian untuk mengetahui nilai keanekaragaman yaitu secara deskriptif kuantitatif. Data diolah menggunakan rumus indeks kenaekaragaman, kemudian hasil perhitungan dianalisis secara deskriptif di dalam pembahasan.

Rumus indeks keanekaragaman menggunakan rumus Indeks Shannon-Weiner $\left(H^{\prime}\right)$, nilai berkisar antara 1,5-3,5 dan sangat jarang bernilai lebih dari 4. Makin tinggi niali $H^{\prime}$, maka makin tinggi pula nilai keanekaragamannya (Rozak, 2020).

$$
H^{\prime}=-\sum_{i=1}^{S}(P i \ln P i)
$$

Keterangan :

$H^{\prime}$ : Indeks Keanekaragaman Shannon-Wiener

$S$ : Jumlah spesies

$\mathrm{Pi}$ : Jumlah individu suatu spesies / jumlah individu total seluruh spesies.

$\mathrm{Ni}$ :Jumlah individu spesies-i

$\mathrm{N}$ :Jumlah total individu.

Menurut Sirait (2018), besarnya indeks keanekaragaman $\left(H^{\prime}\right)$ dalam rumus Shannon-Wiener didefinisikan sebagai berikut : $H^{\prime}=>3$, Indeks keanekaragaman tinggi. $H^{\prime}=1-3$, Indeks keanekaragaman sedang. $H^{\prime}=<1$, Indeks keanekaragaman rendah.

\section{Hasil dan Pembahasan}

\section{Hasil}

Tabel 1. Pengukuran Faktor Lingkungan

\begin{tabular}{|c|c|c|c|c|c|}
\hline \multirow[b]{2}{*}{ Lokasi } & \multicolumn{5}{|c|}{ Faktor Lingkungan } \\
\hline & Ketinggian & $\begin{array}{l}\text { Suhu } \\
\text { Udara }\end{array}$ & Kelembapan & $\begin{array}{c}\text { Suhu } \\
\text { Tanah }\end{array}$ & $\mathrm{pH}$ Tanah \\
\hline $\begin{array}{c}\text { Kawasan Air } \\
\text { Terjun } \\
\text { Lombongo }\end{array}$ & $\pm 800 \mathrm{mdpl}$ & $21^{\circ} \mathrm{C}$ & $97 \%$ & $25^{\circ} \mathrm{C}$ & 5.0 \\
\hline
\end{tabular}


Tabel 2. Daftar Spesies yang Teridentifikasi di Kawasan Air Terjun Lomobongo

\begin{tabular}{cccc}
\hline No & Nama Spesies & Cara hidup & Nama Lokal \\
\hline 1. & Piper sarmentosum & Terestrial & Karuk \\
\hline 2. & Piper cubeba & Epifit & Kemukus \\
\hline 3. & Piper molissimum & Epifit & - \\
\hline 4. & Piper sp. 1 & Terestrial & - \\
\hline 5. & Piper magnibacum & Epifit & - \\
\hline 6. & Piper bantamase & Terestrial & Kayu Sirih \\
\hline 7. & Piper aduncum & Terestrial & - \\
\hline 8. & Piper sp. 2 & Epifit & - \\
\hline 9. & Piper sp. 3 & Terestrial &
\end{tabular}

Ketereangan : Ada dua cara hidup yang ditemukan dari total spesies yang teridentifkasi yaitu terrestrial dan epifit.

Tabel 3. Indeks Keanekaragaman Tumbuhan Suku Piperaceae

\begin{tabular}{|c|c|c|c|c|c|c|c|}
\hline No & Nama Spesies & $\begin{array}{c}\text { Jumlah } \\
\text { Individu }\end{array}$ & $\mathbf{P i}$ & Ln Pi & $\begin{array}{c}\text { Pi Ln } \\
\text { Pi }\end{array}$ & $\mathbf{H}^{\prime}$ & Kriteria \\
\hline 1 & Piper sarmentosum & 11 & 0.14 & -1.93 & 0.28 & \multirow{10}{*}{2.17} & \multirow{10}{*}{ Sedang } \\
\hline 2 & Piper cubeba & 9 & 0.12 & -2.13 & 0.25 & & \\
\hline 3 & Piper molissimum & 9 & 0.12 & -2.13 & 0.25 & & \\
\hline 4 & Piper sp. 1 & 8 & 0.11 & -2.25 & 0.24 & & \\
\hline 5 & Piper magnibacum & 9 & 0.12 & -2.13 & 0.25 & & \\
\hline 6 & Piper bantamense & 10 & 0.13 & -2.03 & 0.27 & & \\
\hline 7 & Piper aduncum & 8 & 0.11 & -2.25 & 0.24 & & \\
\hline 8 & Piper sp. 2 & 4 & 0.05 & -2.94 & 0.15 & & \\
\hline 9 & Piper sp. 3 & 8 & 0.11 & -2.25 & 0.24 & & \\
\hline & Jumlah & 76 & & & & & \\
\hline
\end{tabular}

\section{Pembahasan}

Kawasan air terjun Lombongo sub wilayah Taman Nasional Bogani Nani Wartabone resort Lombongo merupakan kawasan hutan dataran tinggi yang memiliki indeks keanekaragaman sedang. Menurut Sirait, 2018, indeks keanekaragaman yang sedang pada suatu wilayah menggambarkan keseimbangan ekosistem yang cukup stabil. Hal ini menunjukkan bahwa, kawasan air terjun Lombongo merupakan kawasan yang ekosistemnya masih cukup terjaga di tengah-tengah adanya tekanan ekologis. Tekanan ekologis yang dimaksud adalah aktivitas ekowisata karena Lombongo 
merupakan salah satu kawasan wisata yang berada di Taman Nasional Bogani Nani Wartabone. Tekanan ekologis juga dapat mempengaruhi kestabilan suatu ekosistem. Indriyanto, 2006, mengatakan bahwa nilai keanekaragaman menunjukan kestabilan suatu komunitas, di mana kestabilan merupakan dasar keanekaragaman suatu ekosistem.

Berdasarkan hasil penelitian yang dilakukan pada lokasi penelitian, tepatnya di Taman Nasional Bogani Nani Wartabone (TNBNW), di wilayah rintisan geopark kawasan air terjun Lombongo, Desa Lombongo, terdapat 9 jenis tumbuhan suku Piperaceae dengan total 76 spesies yaitu Piper sarmentosum, Piper cubeba, Piper molissimum, Piper sp. 1, Piper magnibacum, Piper bantamense, Piper aduncum, Piper sp. 2, Piper sp. 3, dengan cara hidup berbeda-berbeda. Spesies yang paling banyak dijumpai pada lokasi penelitian adalah Piper sarmentosum dengan total individu sebanyak 11 spesies. Substrat alami tumbuhan Piperaceae yang ditemukan di kawasan air Terjun Lombongo, ada beberapa jenis yang hidup langsung di atas permukaan tanah dengan perawakan berupa semak dan ada juga jenis yang cara hidupnya merambat (Epifit) pada batang pohon (Tabel 2). Tumbuhan suku Piperaceeae merupakan tumbuhan berbunga berupa semak atau perdu dan seringkali merambat dengan menggunakan akar lekat (Munawaroh, 2017)

Penelitian yang dilakukan oleh Munawaroh, 2017, di Taman Nasional Bukit Barisan Selatan (TNBSS) pada ketinggian lokasi yang hampir sama dengan kawasan air terjun Lombongo mencatat indeks keanekaragaman yang cukup stabil, hal ini menunjukan bahwa ketinggian lokasi juga mempengaruhi keanekaragaman tumbuhan, termasuk suku Piperaceae. Selain ketinggian, beberapa faktor lingkungan yang tercatat dalam lokasi penelitian di antaranya kelembaban, suhu udara, $\mathrm{pH}$ dan suhu tanah (Tabel 1).

Suhu udara pada kawasan air terjun Lombongo $21^{\circ} \mathrm{C}$ dengan kelembaban yang cukup tinggi yakni 97\%, di mana suhu dan kelembapan merupakan realitas terbalik. Jika suhu pada suatu kawasan tinggi maka kelembapannya rendah, sebaliknya jika suhu pada suatu kawasan rendah maka kelembapannya akan meningkat. Wijayanto, 2012 mengatakan bahwa suhu dan kelembapan merupakan komponen iklim mikro yang masing-masing saling berkaitan dalam mewujudkan keadaan lingkungan yang optimal bagi pertumbuhan tanaman. Selain itu, suhu tanah pada kawasan air terjun Lombongo berada pada nilai $25^{\circ} \mathrm{C}$ dengan $\mathrm{pH}$ tanah sebesar 5.0. Faktor lingkungan sangat berperan dalam tumbuh kembang tumbuhan, khususnya tumbuhan Piperaceae. Januwati, 1992, mengatakan bahwa faktor lingkungan yang sangat berpengaruh pada kelangsungan hidup tumbuhan Piperaceae meliputi iklim, ketinggian tempat dan jenis tanah, dengan demikian faktor lingkungan juga akan mempengaruhi keanekaragaman tumbuhan Piperaceae.

Indeks keanekaragaman tumbuhan Piperaceae di kawasan air terjun Lombongo memiliki nilai $\left(H^{\prime}\right)$ sebesar 2,17 (Tabel 3). Nilai ini menunjukan bahwa jumlah jenis di antara total keseluruhan individu berada pada kategori sedang. Hasil ini dibuktikan dengan penelitian yang dilakukan oleh Baderan, 2019, di lokasi geosit Provinsi Gorontalo di mana kawasan air terjun Lombongo yang merupakan sub wilayah dari daerah rintis geopark Provinsi Gorontalo memiliki nilai indeks keanekaragaman sedang. Nilai keanekaragaman $\left(\mathrm{H}^{\prime}\right) 1<\mathrm{H}^{\prime}<3$ mengartikan bahwa keanekaragaman jenis pada suatu wilayah atau kawasan adalah sedang, kestabilan dan penyebaran individu tiap jenis juga sedang (Sirait, 2018). Tinggi rendahnya nilai keanekeragaman suatu jenis dipengaruhi oleh banyaknya jenis dan jumlah individu yang teridentifikasi. Menurut Destaranti $d k k$, 2017, semakin banyak jenis yang ditemukan semakin tinggi pula nilai indeks keanekaragaman, semakin tinggi nilai keanekaragaman maka semakin stabil komunitasnya.

Keanekaragaman jenis tumbuhan Piperaceae yang ada di Indonesia masih sedikit dibandingkan dengan total jenis Piperaceae yang ada di dunia, yaitu sekitar 
2.658 ( The Plant List, 2021). Teridentifikasi total spesies Piperaceae yang ada di Indonesia ada 43 jenis (Backer dan Bakhuizen, 1965) atau $\pm 1.62 \%$ dari total jumlah jenis Piperaceae yang ada di dunia. Jumlah ini diyakini akan terus bertambah dikarenakan intensitas kajian dan penelitian terkait keanekaragaman flora dan fauna di Indonesia yang terus meningkat. Penelitian Munawaroh dan Muzammi, 2017, di Taman Nasional Bukit Barisan Selatan (TNBBS) di Provinsi Lampung, sedikitnya menemukan 21 jenis Piperaceae atau sekitar 48.84\% dari total Piper yang ada di Indonesia. Sedangkan pada Taman Nasional Bogani Nani Wartabone di Provinsi Gorontalo resort Lombongo kawasan air terjun Lombongo teridentifikasi total 9 jenis Piperaceae atau sekitar $20.93 \%$ dari total jenis Piper yang ada di Indonesia.

Perbedaan jumlah jenis yang ditemukan sangat bergantung pada kondisi lingkungan, ketinggian tempat dan iklim. Suhu dan Kelembapan pada lokasi TNBBS berkisar antara $28^{\circ} \mathrm{C}$ dengan kelembapan $82 \%$, sedangkan suhu dan kelembapan di TNBNW berkisar antara $21^{\circ} \mathrm{C}$ dengan kelembapan 97\%. Menurut Destarantidkk, 2017, kelembapan yang terlalu tinggi akan menghambat proses transpirasi pada tumbuhan yang akan berdampak pada terhambatnya penyerapan air dan garam mineral dari dalam tanah oleh tumbuhan. Hal ini merupakan fakotr alami yang dapat menghambat tumbuh kembang tumbuhan dalam suatu ekosistem.

Secara keseluruhan Piperaceae merupakan kelompok tumbuhan yang mempunyai nilai tinggi, baik dari segi ekologi, kesehatan maupun ekonomi. Selain itu, tumbuhan Piperaceae juga dapat dimanfaatkan sebagai tanaman hias dan pada beberapa kasus, tumbuhan Piperaceae juga digunakan dalam aktivitas kebudayaan (Menyirih). Beberapa jenis tumbuhan Piper yang hidup secara terestrial yang dikelompokkan ke dalam tumbuhan bawah sebagai lantai hutan mempunyai peran ekologis dalam menyerap air dan mencegah terjadinya erosi. Selain itu, Piperaceae juga dapat dimanfaatkan sebagai tanaman herba. Kandungan minyak atsiri yang terdapat dalam tumbuhan Piper dapat digunakan untuk mengobati keputihan, bau mulut dan radang tenggorokan (Sopandi, 2011).

\section{Kesimpulan}

Penelitian ini menyimpulkan bahwa hasil penelitian di wilayah Taman Nasional Bogani Nani Wartabone kawasan air terjun Lombongo Provinsi Gorontalo ditemukan 9 jenis tumbuhan dari suku Piperaceae dengan total 76 individu dan memiliki 2 pola pertumbuhan yang berbeda, yakni terstrial dan epifit. Jenis Piper dengan jumlah individu terbanyak yakni Piper sarmentosum dan yang paling sedikit ialah Piper sp. 2. Hasil indeks keanekaragaman suku Piperaceae di kawasan air terjun Lombongo dengan menggunakan rumus indeks keanekaragman Shannon-Wiener didapati nilai $H^{\prime}$ 2.17 dengan kriteria sedang yang menunjukan keadaan ekosistem yang cukup stabil.

\section{Daftar Pustaka}

Destaranti, N.. Sulistyani, Yani E. 2017. Struktur dan Vegetasi Tumbuhan Bawah Pada Tegakan Pinus di RPH Kalirajut dam RPH Baturaden Banyumas. Scripta Biologica, 4(3): 155-160.

Rozak, H. A., Sri Astutik, Zaenal M., Endah S., Didik W. 2020. Efektifitas Penggunaan Tiga Indeks Keanekaragaman Pohon Dalam Analisis Komunitas Hutan; Studi Kasus di Taman Nasional Gunung Gede Pangrango, Indonesia. Journal of Forest Research and Nature Conservation, 17(1):35-47 
Sirait M, Rahmatia F, Patulloh. 2018. Komparasi Indeks Keanekaragaman dan Indeks Dominansi Fitoplankton di Sungai Ciliwung Jakarta. Journal of Marine, 11(1).

Wijayanto, Nurheni dan Nurunnajah. 2012. Intensitas Cahay, Suhu, Kelembapan dan Perakaran Lateral Mahoni (Swietenia macrophylla King.) di RPH Babakan Madang, BPKH Bogor, KPH Bogor. Jurnal Silvikultur Tropika, 3(1): 8-13.

Munawaroh E, Astuti, I. P., Sumanto. 2011. Studi Keanekeragaman dan Potensi Suku Piperaceae di Sumatera Barat. Hayati Edisi Khusus. 5 : 35-40.

Munawaroh, Esti dan Yuzammi. 2017. Keanekaragaman Piper (Piperacaeae) dan Konservasinya di Taman Nasional Bukit Barisan Selatan, Provinsi Lampung. Bogor : Pusat Konservasi Tumbuhan Kebun Raya, LIPI.

Januwati, M: Faktor-Faktor Ekologi Yang Mempengaruhi Pertumbuhan Tanaman Sirih (Piper betlle LINN.) 1992, 1(1)

The Plant List. 2021. Piperaceae. https:/theplantlist.org/1.1/browse/Piperaceae (diakses pada tanggal 7 Februari 2021)

UNESCO. 2006. "Guidelines and Criteria for National Geoparks Seeking UNESCO's Assistence to Join in The GGN (Global Geoparks Network)"

Indriyanto. 2006. Ekologi Hutan. Jakarta : PT Bumi Aksara. Hal 59.

Kristanto, Ady dan Momberg, Frank. 2008. Alam Jakarta : Panduan Keanekaragaman Hayati yang Tersisa di Jakarta. Jakarta : Jakarta Murai Kencana

Sopandi. 2011. Tanaman Obat Tradisional(Jilid II). Bandung: PT Sarana Panca Karya Nusa

Sugiyono. 2018. “Metode Penelitian Kuantitatif, Kualitatif dan R\&D”. Bandung : Alfabeta

Baderan, Dewi Wahyuni K. 2016. Keanekaragaman Jenis Tumbuhan Di Kawasan Pesisir Tabulo Selatan, Kabupaten Bualemo, Provinsi Gorontalo. Prosiding Seminar Nasional Lahan Basah. Jilid 1:41-44. ISBN: 978-602-6483-33-1. Gorontalo

Baderan, Dewi Wahyuni K., Angio H. Melisnawati. 2019. Laporan Akhir Pengukuran Indeks Biodiversitas dari Geosite di Provinsi Gorontalo (Suatu Rintisan Geopark). Badan Perencanaan, Penelitian, dan Pengembangan Daerah (BAPPPEDA). Provisi Gorontalo 